Det vita fältet III. Samtida forskning om högerextremism

specialnummer av Arkiv. Tidskrift för sambällsanalys, nr 5 (2016)

\title{
Hundra år av radikal nationalism
}

\section{Markus Lundström \& Tomas Lundström}

SAMMANDRAG: Markus Lundström och Tomas Lundströms artikel analyserar vad författarna benämner som "radikal nationalism" i Sverige mellan 1915-20I5. Utifrån tidigare forskning sammanställs en historisk översikt över de aktörer vars politiska projekt tar sin utgångspunkt i nationalismens själva rot: att knyta en nedärvd folkgemenskap till en specifik plats. Till skillnad från tidigare konceptualiseringar av denna politiska miljö utgår "radikal nationalism" från aktörernas egen idévärld, och genom att betona aktörernas gemensamma ideologiska drag framträder en bild av ett historiskt föränderligt flätverk där olika aktörer skapas och splittras, interagerar, förgrenas och återuppstår. Författarna identifierar tre olika idéströmningar som präglar miljön och som under hundra år av radikal nationalism korsat varandras färdriktning. Medan den rasorienterade och socialkonservativa nationalismen historiskt sett stått i konflikt med varandra, tycks den identitära idéströmningen på senare tid ha skapat nya kontaktytor aktörerna emellan. Artikelns historisering av svensk radikal nationalism föreslår, med andra ord, en analysram för att studera dessa aktörer, och för att begripliggöra nationalistisk radikalisering i Sverige.

NYCKELORD: radikal nationalism; högerextremism; fascism; rasism; socialkonservatism; den identitära rörelsen.

PUBLICERINGSHISTORIK: Originalpublicering.

MARKUS LUNDSTRÖM är doktorand i ekonomisk historia vid Stockholms universitet. E-POSTADRESS: markus.lundstrom@ekohist.su.se

TOMAS LUNDSTRÖM studerar masterprogrammet i religion i fred och konflikt vid Uppsala universitet.

FÖRSLAG PÅ KÄLLANGIVELSE:

Lundström, Markus \& Tomas Lundström (20I6) "Hundra år av radikal nationalism", i Det vita fältet III. Samtida forskning om högerextremism, specialnummer av Arkiv. Tidskrift för samhällsanalys, nr 5, s. 39-66. DOI: http://dx.doi.org/IO.I3068/2000-6217.5.2

(C) Författarna/Arkiv förlag \& tidskrift 20 6 (publicerad I8 april 20ı6)

Artikeln distribueras enligt en upphovsrättslicens från Creative Commons: Erkännande-Ickekommersiell-IngaBearbetningar 3.0 Unported, som medger fri ickekommersiell användning och spridning i oförändrat skick så länge källan anges. 
Arkiv. Tidskrift för samhällsanalys är en sakkunniggranskad vetenskaplig tidskrift för samhällsvetenskap och historia. Samtliga artiklar publiceras fritt tillgängliga på:

$$
\text { www.tidskriftenarkiv.se }
$$

(beständig länk, DOI: http://dx.doi.org/IO.I3068/200o-62I7)

Den här artikeln finns tillgänglig i följande format:

PDF \& HTML: via beständig länk, DOI: http://dx.doi.org/IO.I3068/2000-62I7.5.2 EPUB: ingår i e-boksutgåva av numret, ISBN: 978 9I 79242763

TRYCK: ingår i bokutgåva av numret, ISBN: 978 9I 7924277 O

Grafisk utformning och sidnumrering är identisk i pdf och tryck.

Samtliga artiklar i nr 5 (20I6), Det vita fältet III. Samtida forskning om högerextremism, nås via beständig länk, Dor: http://dx.doi.org/I0.13068/2000-6217.5

Redaktion för numret: Mats Deland, Paul Fuehrer, Fredrik Hertzberg och Thomas Hvitfeldt

Arkiv. Tidskrift för samhällsanalys ISSN: 2000-62I7 (för elektronisk resurs) ISSN: 2000-6225 (för tryckta nummer)

ges ut av

Stiftelsen Arkiv för främjande och spridning av samhällsvetenskaplig och historisk forskning

genom

Arkiv förlag \& tidskrift

Box 1559 SE-22I OI Lund вESÖк: L Gråbrödersg 3 c, ipg TEL: O46-I3 3920

ARKIV FÖRLAG: arkiv@arkiv.nu·www.arkiv.nu TIDSKRIFTEN ARKIV: red@tidskriftenarkiv.se · www.tidskriftenarkiv.se

ANSVARIg UTGIVARE \& CHEFREDAKTÖR: Sven Hort AdMinistrativ Redaktör: David Lindberg Redaktörer: Paavo Bergman, Lisa Kings, Zhanna Kravchenko 


\section{Hundra år av radikal nationalism}

\section{MARKUS LUNDSTRÖM \& TOMAS LUNDSTRÖM}

Hösten I9I5, samtidigt som skyttegravarna börjar grävas vid första världskrigets västfront, bildas organisationen Sveriges nationella ungdomsförbund på hotell Kronprinsen i Stockholm. Mitt under brinnande världskrig - ett krig som i nationalismens namn skulle komma att kräva miljontals människoliv - skapas en organisation med syftet att, som det hette, främja kärlek till fosterlandet (Wärenstam 1965, s. 3). Sveriges nationella ungdomsförbund markerar den organisatoriska startpunkten för detta radikala politiska projekt, som syftar till att befästa och försvara nationalismens grundläggande principer. Under historiens gång har en rad aktörer, med varierande politisk framgång, bejakat det politiska projekt som vi i den här artikeln benämner "radikal nationalism”. Vi kommer att följa detta projekt över hundra år och identifiera tre idéströmningar som möjliggjort beröringsytor och positioneringar mellan historiska och samtida radikalnationalistiska aktörer. I den här studien ämnar vi fortsätta det definierande arbete som påbörjats av tidigare forskning genom att laborera med en induktivt utarbetad konceptualisering. I detta syfte har vi sammanställt ett historiskt flödesschema över de aktörer som av tidigare forskning definierats som högerextrema, fascistiska, nazistiska eller som del av vitmaktvärlden. Under hundra år av radikal nationalism förekommer ständiga splittringar, förgreningar och hopfogningar inom vad som kan liknas vid ett flätverk. Vi avser att översiktligt teckna denna utveckling och påbörja en teoretisk analys av 
detta svenska radikalnationalistiska flätverk. Vi inleder med en begreppsdiskussion, och kommer därefter att fortsätta analysen genom en huvudsakligen kronologisk genomgång, innan den avslutande diskussionen.

\section{Den radikala nationalismen}

Det finns i dag en rad olika samlingsbegrepp för det historiskt brokiga sammanhang som rymmer motstridiga aktörer såsom Sveriges nationella förbund och Nordiska rikspartiet, Sverigedemokraterna och Svenska motståndsrörelsen. Aktörerna själva identifierar sig oftast som nationella, eller nationalister. Deras uttolkare har emellertid använt andra konceptualiseringar - numera främst högerextremism och fascism - för att med vetenskapliga metoder studera aktörerna. Den skiftande begreppsanvändningen kan tolkas som att begreppen har olika förtjänster vad gäller att belysa enskilda sidor av studieobjektet. Under de senaste åren har emellertid samhällsforskningen i Sverige kommit att förhålla sig alltmer kritiskt till de olika begreppens förklaringsvärde. Ett viktigt steg i denna riktning har tagits genom publiceringsinitiativet Det vita fältet.

I förordet till den första volymen i serien förklaras varför det underutforskade område som avses - "det vita fältet" - definieras i termer av "högerextremism" (Deland m.fl. 20Io, s. 5 ff.). Författarna anger att begreppets kärna utgörs av åtskillnad mellan folkgrupper. Denna åtskillnadspolitik antar "negativt" uttryckta benämningar - anti-feminism, anti-sionism, anti-islamism, anti-globalisering - samt "positiva" uttryck i form av starka ledare, acceptans för politiskt våld och subkulturellt utforskande (Deland m.fl. 20Io, s. 5 ff.). Begreppet "högerextremism" har emellertid en rad analytiska begränsningar. Ett första problem, som också påpekas av Det vita fältets redaktörer, är att högerextremismens attribut varierar kraftigt mellan de aktörer som definitionen är tänkt att omfatta. Högerextremism blir påtagligt vilseledande när aktörerna betonar statsledd social välfärd och ekonomisk utjämning. Efterledet extremism implicerar dessutom ett avvikande från den politiska huvudfåran, en missvisande beskrivning med tanke på valutgången i 2014 års riksdagsval där Sverigedemokraterna blev Sveriges tredje största parti. Ett angränsande analytiskt problem är att talet om extremism förutsätter en 
dikotom tankefigur, där de (extrema) särskiljs från oss (normala), vilket tenderar att osynliggöra idéer och praktiker som återfinns på båda sidor av motsatsparet.

En alternativ begreppsbildning skulle i stället kunna utgå från aktörernas egen idévärld. Ett redan existerande exempel på en sådan konceptualisering, välanvänd både i och utanför den akademiska världen, är att tala om aktörerna som del av en vitmakt-miljö. Begreppet "vit makt" (white power) myntades på 1960-talet, av ledaren för American Nazi Party, och var ett direkt svar på den samtida Black Power-rörelsen i USA. Konceptet syftade till att överskrida nationella motsättningar som hindrade den "vita rasen" från att samarbeta på ett transnationellt plan (Gardell 2007, s. 30 ff.; Lööw 20I5, s. II2 ff.). I Sverige kom begreppet under 1980- och 1990-talen att knytas till en specifik musikscen, för att sedan referera till politiska aktörer som på olika sätt varit kopplade till denna vitmaktmusik. Även om begreppet "vit makt" ursprungligen var självdefinierande är det värt att understryka att dagens aktörer inte ser sig själva som en del av vitmaktmiljön. I stället uppfattar dessa aktörer sig själva som nationalister, dessutom i en transnationell bemärkelse, vilket vi kommer att beröra senare i artikeln.

Ett analytiskt problem med talet om vitmaktmiljön är att en rad självdefinierat nationalistiska aktörer inte omfattas av denna begreppsbildning. Historikern Heléne Lööw (2015, s. I27), som under flera decennier studerat nazismen i Sverige, använder sig framför allt av begreppet "vit makt" för att hålla samman sina studieobjekt. Samtidigt laborerar Lööw (20I5, s. II, 22) med en analytisk indelning mellan vad hon kallar rasideologiska och extremnationalistiska aktörer, vilket tycks beteckna samtida varianter av historisk nationalsocialism respektive fascism. Då en aktör som Sverigedemokraterna av Lööw (2015, s. 182, 230) kategoriseras som extremnationalism aktiveras emellertid den ovan nämnda problematik som finns inbyggd i denna term. Lööw (2015, s. I3 f.) poängterar själv hur extremismbegreppet tenderar att tränga undan ideologiska förklaringar till de samhällsfenomen hon undersöker.

I den här artikeln kommer vi därför att studera hur olika ideologiska strömningar bidrar till att knyta samman, men också splittra, de aktörer som tidigare benämnts med hjälp av analytiska samlingsbegrepp som 
"högerextremism" och "vitmaktmiljö". Studiens metodologiska fokus blir därmed att undersöka det ideologiska kitt som länkar samman dessa historiska och samtida aktörer. Heléne Lööw (2015, s. I2 ff., 34, 130) definierar aktörernas sammanlänkande tema som intolerans mot minoritetsgrupper, där antisemitismen spelar en särskilt avgörande roll för den historiska kontinuiteten. Ett liknande angreppssätt är Ov Cristian Norocels (2013a, s. 27 ff.; 2013b, s. 62 f.) identifikation av antifeminismen som samlande artikulationskraft, en argumentation som delvis reflekterar historikern George Mosses (1996, s. I55 ff.) forskning om den historiska fascismens manlighetsideal. Ett kompletterande angreppssätt, som till viss del överskrider fokus på den gemensamma negationen (anti-feminism, anti-semitism), är att undersöka de ideologiska meningsbärare som för aktörerna anses vara positiva, konstruktiva, affirmativt framåtsyftande. Ett viktigt bidrag har här gjorts av Mattias Gardell (2007, s. 56 ff.), som utifrån sin fältstudie i USA anger strävan efter etnisk homogenitet som gemensam nämnare. Trots påtagliga skillnader på skalorna högervänster och centralism-decentralism, framhåller Gardell att kravet på homogenitet, utifrån etnicitet och sexuell läggning, gäller för samtliga av de aktörer han studerar.

För att fortsätta det definierande arbete som påbörjats av tidigare forskning har vi sammanställt ett historiskt flödesschema över de aktörer som av tidigare forskning definierats som högerextrema, fascistiska, nazistiska eller som del av vitmaktvärlden. Utifrån denna uppställning har vi sökt identifiera dessa aktörers gemensamma nämnare - den meningsbärande ideologiska grundkomponenten - varvid vi identifierat nationalismen som central politisk artikulationskraft. För att på ett analytiskt plan precisera denna nationalism föreslår vi att den ska betecknas som radikal. I etymologisk bemärkelse syftar radikal på att "gå till roten" (från latinets radix, rot), medan natio anger födelse, folk eller ras. Den radikala nationalismen bejakar alltså nationalismens själva rot: det politiska projekt som kännetecknas av att knyta en nedärvd folkgemenskap till en geografisk plats.

Vårt historiska flödesschema har utarbetats genom att sammanställa tillgänglig data för aktörernas start- och slutår, samt vilka kopplingar som finns mellan dessa organisationer. De aktörer vi presenterar i före- 
liggande genomgång syftar inte till att ge en heltäckande bild av de otaliga partier, organisationer och tankesmedjor som varit aktiva inom de senaste hundra årens radikala nationalism. Syftet är i stället att illustrera hur aktörer skapas och splittras, förgrenas och återuppstår, samt hur de på detta sätt bildar något som kan liknas vid ett flätverk, en helhet där den svenska radikala nationalismen flätats samman under åren 19152015 (se figuren nedan, sidorna 58-59). Dessa sammanflätningar - kopplingar aktörerna emellan - förstås i vår studie som nyckelpersoners förflyttningar mellan organisationer, alternativt när en organisation grundar en annan. Den empiriska genomgången bygger huvudsakligen på sekundärkällor, och då i första hand granskade forskningsrapporter. Det bristande akademiska forskningsläget har emellertid gjort det nödvändigt att komplettera med journalistiskt material, i synnerhet från Stiftelsen Expo.

Vid sidan av dessa sekundärkällor har vi även studerat ett begränsat urval av aktörernas egna texter (partiprogram, internetpublikationer och poddradioprogram), i syfte att illustrera hur dessa aktörer inspireras av den radikala nationalismens olika idéströmningar. Även om dessa primärkällor i första hand har en illustrativ funktion, överbryggar de också några av de empiriska luckor vi funnit hos sekundärkällorna. Utifrån vår problemformulering finns det nämligen en påtaglig brist med både den journalistiskt och den akademiskt producerade empirin. Dessa texter har ofta ett uttalat deskriptivt fokus, med ingående beskrivningar av individer och organisationer, vilket tycks ha begränsat analysen av ideologiska överlappningar aktörerna emellan. Ett exempel är Heléne Lööws många forskningsalster, i vilka ideologianalyser och övergripande slutsatser ofta tonas ned till förmån för den rika empiriska återgivningen. Förutom att begränsa djupgående analyser tenderar ett individfokuserat aktörsperspektiv, menar vi, att osynliggöra kopplingen till den kontext - det politiska klimatet i Sverige - inom vilken den radikala nationalismen aktiveras.

I vår schematiska kartläggning har vi därför sökt förflytta oss från denna individorienterade empiriska nivå. I stället har vi undersökt hur olika aktörer och idéströmningar flyter samman. Vi har medvetet undvikit att referera till specifika individer och i stället betonat dessa personers 
roll i respektive organisation, för att på så sätt underbygga det analytiska fågelperspektiv som anger ramarna för vår historiska studie. Utifrån det tillgängliga forskningsläget ämnar vi alltså undersöka det ideologiska kitt som sammanfogar det svenska radikalnationalistiska flätverket.

\section{Det radikalnationalistiska flätverket}

I den här artikeln argumenterar vi för att det historiska flödesschema, som illustreras på sidorna 58-59, lämpligtvis kan rubriceras med hjälp av begreppet "radikal nationalism". I det avslutande avsnittet diskuterar vi nationalismens meningsskapande funktion för det radikalnationalistiska flätverket, medan följande empiriska avsnitt beskriver dess historiska splittringar, förgreningar och hopfogningar. För att differentiera flätverkets sammansättning har vi funnit det användbart att indela den radikala nationalismen i tre idéströmningar: rasorienterad, socialkonservativ och identitär nationalism. De tre inriktningarna bör förstås som idealtyper, analytiskt konstruerade i syfte att synliggöra historiska förvecklingar inom den svenska radikala nationalismen. Flätverkets aktörer hämtar i varierande grad inspiration ifrån dessa tre idékällor. Den historiskt sett mest inflytelserika av dessa idéströmningar - som i dag återspeglas hos exempelvis Sverigedemokraterna - är den socialkonservativa nationalismen.

\section{Socialkonservativ nationalism}

Den organiserade svenska radikalnationalismen har ingen självklar historisk startpunkt. Heléne Lööws (2015, s. 23) historisering inleds med bildandet av Svenska nationalsocialistiska frihetsförbundet i augusti 1924. Historikern Eric Wärenstam, som på 1960-talet öppnade forskningsfältet om fascism och nationalsocialism i Sverige, indikerar emellertid att bildandet av Sveriges nationella ungdomsförbund, den I6 oktober I9I5, utgör den radikala nationalismens första organisatoriska uttryck (Wärenstam I965, s. 3, 283). Detta är också en lämplig startpunkt för vår studie, då Sveriges nationella ungdomsförbund tydligt slår an tonen för den socialkonservativa nationalismen.

Sveriges nationella ungdomsförbund agerar under den första tiden som fristående ungdomsförbund till Allmänna valmansförbundet (dagens 
Nya moderaterna), framför allt fokuserat på att stärka den svenska försvarsmakten. Enligt Wärenstam blir emellertid idén om en etniskt homogen folkgemenskap under 1930-talet alltmer meningsbärande i förbundets militaristiska omvärldsanalys. År 1934 sker en brytning med Högern (som Allmänna valmansförbundet nu kallades), och organisationen formeras nu som ett självständigt politiskt parti: Sveriges nationella förbund. År 1937 ansluter sig frontfiguren i den så kallade Nysvenska rörelsen (Wärenstam I970, s. I37 ff.; Lööw 20I5, s. 33 f.). Fyra år senare, 194I, avknoppas organisationen Svensk opposition för att sedermera återta namnet Nysvenska rörelsen (Berggren 20I4, s. 75 f.; Lööw 20I5, s. 34).

Genom Sveriges nationella förbund och Nysvenska rörelsen grundläggs idén om folkgemenskapens betydelse för det svenska territoriets bevarande, en bärande tankefigur också inom den historiska nationalsocialismen (Wärenstam 1965, s. 3, 285; Lööw 1990, s. 222). Samtidigt tycks dessa organisationer ha försökt distansera sig från nationalsocialismen, såväl Hitlers expansiva politik som nationalsocialistiska organisationer i Sverige (Lööw 2004, s. I8I ff.). Enligt historikern Lena Berggren (20I4, s. 75 f.) är Sveriges nationella förbund, åtminstone fram till 1940, främst ett konservativt parti, fokuserat på den svenska folkgemenskapen. Under I930-talet artikuleras alltså en spänning inom den radikala nationalismen: konservatismens förespråkande av långsam och gradvis samhällsförändring och nationalsocialisternas revolutionära samhällsanalys.

Denna spänning kom att intensifieras under 1950-talet, när Nysvenska rörelsen tonar ner antisemitismen och ger kategorin "ras" minskat förklaringsvärde i sin politiska analys. I stället framhålls kulturens roll för folkgemenskapens formerande (Lööw 2007, 83 f.). Parat med den konservativa idén om långsam samhällsförändring innebär tonvikten på den svenska kulturen, i stället för på den svenska rasen, ett politiskt projekt i syfte att bevara den kulturellt nedärvda folkgemenskapen. Vi kan på detta sätt tala om en socialkonservativ nationalism. Sveriges nationella förbund och Nysvenska rörelsen, organisationer som förblir verksamma in på 1990- respektive 2000-talet (Berggren 20I4, s. 76, 330; Lööw 20I5, s. 44 f.), lägger med andra ord den ideologiska grunden för den socialkonservativa idéströmningen och dess komplicerade förhållande till den rasorienterade nationalismen. 
Under 1980-talet återaktualiseras den socialkonservativa nationalismen i och med framväxten av den politiska kampanjorganisationen Bevara Sverige svenskt, vars ledande personer alltmer börjar göra avkall på sin tidigare rasorienterade nationalism. Inspirerade av den ideologiska kursändring, som samtidigt deklareras av Nysvenska rörelsen, nedtonas rasbiologin till förmån för idén om folket som kulturellt betingat (Lööw 2000, s. 27 f.; Ekman 20I4, s. 20). Frågan om ras börjar nu splittra den svenska radikala nationalismen. Nordiska rikspartiet (som presenteras nedan) varnar högljutt för Bevara Sverige svenskt och anklagar organisationen för att präglas av "sionism", samt för försök att ta över eller krossa partiet (Lööw 2000, s. 28). Bevara Sverige svenskt fortsätter, trots denna kritik, att röra sig i samma socialkonservativa riktning. Tillsammans med Framstegspartiet bildar de Sverigepartiet 1986. Det nya partiet blir emellertid kortlivat och upplöses redan 1988 efter interna stridigheter, för att i stället ombildas under det nya namnet Sverigedemokraterna (Lööw 2000, s. 26 f.; Ekman 20I4, s. 37 f.).

Sverigedemokraterna ställer upp i riksdagsvalet redan samma år. Enligt Expo-journalisten Mikael Ekman (20I4, s. 4I f.) betraktar partiet valet som en framgång, trots de knappa I Ioo rösterna. Ett år efter grundandet väljs en före detta aktivist inom Nordiska rikspartiet till partiledare för Sverigedemokraterna (Ekman 20I4, s. 42). Under dennes ledning förblir förbindelserna med den rasorienterade nationalismen täta. Journalisten Mathias Wåg (20I4, s. 98) har bland annat pekat på Sverigedemokratisk ungdoms (SDU) grundande av bulletinen Info-I4 och samarbete med tidskriften Storm som framträdande förbindelser. Under den andra hälften av 90-talet gör Sverigedemokraterna dock flera försök att lösgöra sig från kopplingarna till den rasorienterade nationalismen. År 1995 byter partiet ledare och inför uniformsförbud på demonstrationer och manifestationer (Ekman 20I4, s. 6I). Samma år upplöser Sverigedemokraterna sitt ungdomsförbund på grund av dess kopplingar till den rasorienterade nationalismen (Wåg 2014, s. 98).

Efter att stridigheter om framtoning och taktik pågått i partiet under flera års tid utesluts år 200I ett antal framträdande personer ur Sverigedemokraterna på grund av så kallad partiskadlig verksamhet (Ekman 20I4, s. 65). Den lilla kretsen kring dessa personer grundar då partiet 
Nationaldemokraterna, och lockar i och med detta till sig flera lokalavdelningar från Sverigedemokraterna (Ekman 20I4, s. 65). Samtidigt drar Nationaldemokraterna till sig personer från den rasorienterade nationalismen (Wåg 20IO, s. IO5). Det nya partiet har ett nära samarbete med personer kring kretsen runt Info-I4 och Salemmarscherna (presenteras nedan). Nationaldemokraterna upplever dock ett flertal interna strider och lever en tynande tillvaro under 20I0-talet och läggs slutligen ner år 20I4 (Wåg 20I4, s. IOI f.).

En annan av Sverigedemokraternas många förgreningar är kopplingarna till den så kallade kontrajihadistiska rörelsen. Mest betydande är förmodligen nättidningen Avpixlat (tidigare Politiskt inkorrekt), finansierad via en av Sverigedemokraternas riksdagsledamöter (Hannus 20I2, s. 32). Den mer militanta grenen av kontrajihadismen företräds av gruppen Swedish Defence League, som grundas 2010 av personer som varit aktiva i Sverigedemokraterna och föreningen Tryckfrihetssällskapet (Expo 20I2, s. II; Wåg 20I4, s. IO5 f.). Tryckfrihetssällskapet ger i sin tur ut tidningen Dispatch International, som vid grundandet skickas ut till alla medlemmar i Sverigedemokraterna (Quensel 20I4, s. 43).

Den socialkonservativa idéströmningen tycks öppna upp för Sverigedemokraternas många förgreningar. Partiet benämner själv sin ideologi som "en socialkonservatism på tydlig nationalistisk grund", och understryker i samma principprogram från $20 I I$ vikten av "nationalismen och stärkandet av samhörigheten på den nationella identitetens och den gemensamma kulturens och historiens grund" (Sverigedemokraterna 20I4, s. II). Den socialkonservativa nationalismen tycks alltså kännetecknas av viljan att bevara och förstärka en historisk och kulturell folkgemenskap - att konservera det sociala. Den utsatta folkgemenskapen anses hotad av såväl klassklyftor som klasskamp. Men den främsta hotbilden kommer utifrån.

Den socialkonservativa nationalismens utgångspunkt understryker ett resolut bevarande av den nationella kulturen, med den logiska följden att kulturavvikande personer utgör ett allvarligt samhällsproblem (Deland m.fl. 2oro, s. 7 f.). Samtidigt gör förståelsen av långsam kulturell förändring att explicit rasifierande särskiljningar blir överflödiga. Nationen bestäms utifrån det som uppfattas som en historiskt särpräglad 
folkgemenskap, inte utifrån biologi. Det blir därför logiskt att den socialkonservativa nationalismens företrädare kan ta avstånd från rasbiologiska förklaringsmodeller, för att på samma gång driva en hårdför antiinvandringspolitik. Den socialkonservativa nationalismens hundraåriga historia - som inspirerat organisationer från Sveriges nationella förbund och Nysvenska rörelsen till Bevara Sverige svenskt och Sverigedemokraterna - kännetecknas därför av en komplicerad relation till vad vi kallar den rasorienterade nationalismen.

\section{Rasorienterad nationalism}

Denna idéströmning är till stor del inspirerad av den historiska nationalsocialismens hierarkiska raslära, vars föreställning om den vita, ariska, eller nordiska rasens överhöghet motiveras utifrån rasbiologiska förklaringsmodeller (Lööw 2004, s. 339 ff.; Gardell 2007, s. 3I f.). Den rasorienterade nationalismen har därmed ett starkt inslag av vad historikern Lena Berggren (2014, s. 69) identifierat som ett behov av inre renhållning: rashygieniska åtgärder som medvetet adresserar de folkelement som anses avvikande. Vid sidan av rasmässig rangordning har även Berggren, i samklang med andra forskare, identifierat antisemitismen - med funktionen att förklara globala och lokala maktordningar - som ett bärande inslag i denna idéströmning (Gardell 2007, s. 45; Lööw 2007, s. 83 f.; Berggren 20I4, 79 ff.; Fleischer 20I4, s. 55 f.).

Nordiska rikspartiet är den historiskt mest inflytelserika förmedlaren av rasorienterad nationalism i Sverige. Partiets rötter sträcker sig bakåt till Nationalsocialistiska arbetarepartiet, som år 1938 bytte namn till Svensk socialistisk samling för att markera distans till Hitlers expansiva nationalism (Lööw 2004, s. 32, I48, I65 f.). Nationalsocialistiska arbetarepartiet hade tillkommit efter en splittring av Svenska nationalsocialistiska partiet år 1933 - ett parti som i sin tur var sprunget ur Sveriges första parti av detta slag: Svenska nationalsocialistiska frihetsförbundet (Berggren 20I4, s. 72 f.; Lundberg 20I4, s. 56). Enligt historikern Victor Lundberg (20I4, s. 57 f.) bestod denna splittring i en ideologisk positionering mellan arbetarklassorienterad respektive överklassorienterad fascism.

Förutom de nationalsocialistiska rötterna har Nordiska rikspartiet, som bildas 1956, också direkta kopplingar till Sveriges nationella förbund, 
med vilket partiet samarbetar på lokal nivå fram till 1968 (Lööw 2004, s. I84). Nordiska rikspartiets rötter sträcker sig därmed bakåt till både den rasorienterade och den socialkonservativa grenen av den radikala nationalismen. På liknande sätt talar Lööw (2000, s. 23; 2004, s. I63 ff.; 20I5, s. 37 ff.) om Nordiska rikspartiet som en förmedlande länk mellan den historiska nationalsocialismen och de militanta radikalnationalistiska aktörer som växer fram mot slutet av seklet. Under 1980-talet ökar nämligen Nordiska rikspartiets aktivitet. Efter sammandrabbningar med politiska motståndare under ett partimöte i Göteborg, år 1983, uppmanar partiets ledare medlemmarna att kartlägga sina vedersakare (Lööw 2000, s. 24, 33). Detta blir startskottet för Göteborgsavdelningens och grupperingen Riksaktionsgruppens attacker, trakasserier och systematiska kartläggning av politiska meningsmotståndare (Lööw 2000, s. 34 ff.). År 1986 döms två medlemmar i partiet för mord på en homosexuell judisk man i Göteborg, samtidigt som andra partimedlemmar åtalas för bland annat olaga hot, misshandel, mordbränder och skadegörelse (Lööw 2000, s. 38 f.). De spektakulära attentat som karaktäriserar Nordiska rikspartiet under 1980-talet - i medierna omtalat som NRP-härvan - upphör efter rättegångarna. Flera medlemmar lämnar partiet i protest mot våldet, för att i stället gå över till Sverigedemokraterna. Andra lämnar av besvikelse över partiledningens bristande stöd till de dömda aktivisterna (Lööw 2000, s. 46).

År 199I deltar Nordiska rikspartiets ledare i ett möte där en grupp yngre personer bildar det informella nätverk som senare ska komma att kallas Vitt ariskt motstånd (Lööw 2000, s. 8o f.). Denna gruppering plockar alltså upp manteln från 1980-talets konfrontativa gren av Nordiska rikspartiet, men med en avsevärt högre grad av intensitet. Nätverket kring Vitt ariskt motstånd (VAM) gör sig under åren I99I till 1993 kända för en rad bankrån, inbrott, vapenstölder, bombhot och attentat. Trots den relativt korta tid som Vitt ariskt motstånd hålls levande, blir flera framträdande medlemmar i nätverket viktiga för den rasorienterade nationalismens kontinuitet, bland annat genom en rad tidskrifter knutna till nätverket (Wåg 20IO, s. IOI). År 1990 grundas tidskriften Storm som periodvis fungerar som VAM-nätverkets nav (Lööw 2000, s. 80 ff.; Wåg 20IO, s. IO3). Efter att VAM går under jorden år 1993 läggs 
Storm ner och följs upp av musiktidningen Nordland som fram till år 1999 förblir en tongivande röst för den rasorienterade nationalismen. Nordland får i sin tur en efterträdare i form av tidningen Folktribunen år 1997, samtidigt som den kopplas samman med den då nybildade organisationen Svenska motståndsrörelsen (Wåg 20I0, s. IO2 ff.).

Svenska motståndsrörelsen kommer att utgöra en fristående fortsättning av Vitt ariskt motstånd, främst via sin ledare, som varit en av VAM:s nyckelfigurer (Lööw 2000, s. 83). Svenska motståndsrörelsen bildas av organisationen Nationell ungdom, som efter en brytning med Sverigedemokraterna 1997 anser sig behöva en ny moderorganisation (Wåg 20I4, s. IOO). Nationell ungdom hade i sin tur startats år I995, då under namnet Oberoende nationell ungdom, som nytt informellt ungdomsförbund till Sverigedemokraterna efter att SDU upplösts på grund av kopplingarna till den rasorienterade nationalismen (Wåg 20I4, s. 98). Svenska motståndsrörelsen knyter också an till VAM genom sin militanta framtoning. Enligt Lööw (20I5, s. 75) har organisationen trappat upp sina våldshandlingar under oo-talet, och blir rikskända i december 2013 genom en attack på en antirasistisk manifestation i Stockholmsförorten Kärrtorp. Med sin betoning på vit överhöghet, sin explicita antisemitism och sitt idoga försvar av den historiska nationalsocialismen, blir Svenska motståndsrörelsen den organisation som i dagens Sverige öser flitigast ur den rasorienterade idéströmningen, vilket illustreras i nedanstående citat från rörelsens internetportal och nättidning Nordfront.

Nationalsocialismen hyllar rasen och kulturen och slår vakt om folkets intressen. Rasen och kulturen är själva nationalismen i nationalsocialismen. Nationalsocialismen utgår alltid ifrån vad som är bäst för vårt folk. Folket står alltid i fokus (Magnusson 20I4).

En annan av VAM:s många avknoppningar är nyhetsbrevet Info-I4. Ledarfigurer från SDU startar Info-I4 år 1995, som en informell uppföljare till tidningen Storm (Wåg 20I4, s. 98, Io6; AFA Dokumentation 2007, s. 223). Info-I4 spelar under det sena 90-talet en samlande roll, att jämföra med Storms roll under VAM-perioden. Den radikalnationalistiska våldsvågen under år 1999 - mordet på en fackföreningsföreträdare i Sätra, bilbomben mot ett journalistpar i Nacka och polismorden 
i Malexander - försvaras i Info-I4:s specialbilaga Kampnytt som ges ut samma år (Wåg 20I4, s. 98 f.). Info-I4 får emellertid sin främsta betydelse genom att vara huvudarrangör till den politiska manifestationen Salemmarschen, som under oo-talet lyckas ena stora delar av den svenska radikalnationalismen.

Vid sidan av utomparlamentariska förgreningar som Info-I4 och Svenska motståndsrörelsen, göder VAM-nätverket också framväxten av parlamentariska uttryck för den rasorienterade nationalismen. Under sommaren 1994 bildas Nationalsocialistisk front i Karlskrona, av personer med direkt anknytning till Vitt ariskt motstånd. Nationalsocialistisk front växer från att vara ett lokalt fenomen till att på några år bli landsomfattande, med lokalgrupper i ett flertal svenska städer (Lööw 2000, s. 92 f.). År 2008 läggs Nationalsocialistisk front ner av partiledningen, som samtidigt startar partiet Folkfronten och flyttar över medlemmarna till den nya organisationen. Efter ett misslyckande med att registrera namnet Folkfronten byter partiet år 2009 namn till Svenskarnas parti (Ekman 20I3, s. 4). Det nya partiet samlar personer som tidigare varit engagerade i Info-I4, Svenska motståndsrörelsen och i arbetet med Salemmarschen, samt ledande personer från det alltmer borttynande partiet Nationaldemokraterna (Wåg 20I4, s. IOI, III f.). Svenskarnas parti blir på så vis en temporärt viktig knutpunkt för stora delar av den svenska radikala nationalismen. I riksdagsvalet 2014 får Svenskarnas parti emellertid inte det antal röster som förväntats, varpå partiledningen beslutar att upplösa organisationen under våren 2015 .

Sammanfattningsvis tycks den organiserade svenska radikalnationalismen, alltsedan 1930-talet, ha varit kluven i två falanger. Grovt sett hämtar dessa falanger, menar vi, sin ideologiska inspiration från den rasorienterade respektive den socialkonservativa idéströmningen. Skillnaden markeras genom den socialkonservativa nationalismens avståndstagande från rasbiologiska förklaringsmodeller, även om denna idéströmning samtidigt ger klang åt den rasorienterade nationalismens föreställningar om folk och territorium. Den komplicerade relationen - manifesterad i strategiska växlingar mellan avståndstagande och omfamnande - har på så sätt skapat en svårläkt splittring mellan den svenska radikalnationalismens aktörer. Denna historiska skiljelinje mellan rasorienterad och 
socialkonservativ nationalism har accentuerat ett taktiskt behov av en tredje, överbryggande, variant av radikal nationalism.

\section{Identitär nationalism}

Genom att betona den nationella identiteten som huvudsaklig meningsbärare möjliggör den så kallade identitära nationalismen nya fusioner och allianser mellan aktörer som tidigare legat i strid med varandra. Fundamenten för den identitära nationalismen formuleras ursprungligen i I960-talets Frankrike av filosofen Alain De Benoist, en central tänkare inom den så kallade nya högern (nouvelle droite). Benoist förespråkar, inspirerad av den tongivande marxisten Antonio Gramsci, utstuderade strategier för att utmana och omformulera dominerande tankefigurer (Straud 2007, s. 163). En tongivande tillämpning av denna kulturkamp är framställningen av etnisk skillnad utifrån ett rättighetsperspektiv: individens rätt till nationell identitet. Eftersom nationell identitet antas bestämmas utifrån en homogen folkgrupp, uppfattas det mångkulturella projektets "smältdegel" som ett allvarligt hot (Cento Bull 2009, s. 600 ff.). Detta idéarv har motiverat dagens identitära tänkare att, synbarligen motsägelsefullt, kraftigt nedtona nationalstatens betydelse för nationalismen (Wåg 20ıo, s. I2I ff.). Denna ideologiska variant följer emellertid nationalismens bärande idé om en homogen gemenskap (rasmässig och/ eller kulturell), knuten till ett territoriellt avgränsat område. Nationalstaten Sverige kan på detta sätt uppfylla kriterierna för att vara en nation - om territoriet och dess befolkning förblir intakt - men kan likväl förstås som nationens motståndare, som när den genom att tillåta "massinvandring" anses hota folkgemenskapen. I citatet nedan accentuerar en tidigare styrelseledamot för Svenskarnas parti, här som skribent för tankesmedjan Motgift, nödvändigheten att separera staten från nationen:

Som nationalister tror vi på nationen, alltså gemenskapen i det gemensamma ursprunget, kulturen och språket, men vi får aldrig sammanblanda detta med en blind lojalitet till vare sig stat eller land (Eriksson 20I4).

Det identitära idékomplexet kan uttryckas i transnationella termer, exempelvis genom strävan efter att bevara och försvara "västvärlden". Här blir förståelsen av territoriet rörligt, medan folkets "essens" hålls konstant. 
När den territoriella avgränsningen inte definieras av nuvarande nationsgränser underlättas alltså samarbete på transnationell nivå. På samma gång befinner sig den identitära nationalismen på politisk mikronivå, exempelvis genom utforskandet av småskaliga alternativa bygemenskaper baserade på etnisk homogenitet (Wåg 20IO, s. I23; Fleischer 20I4, s. 58). Här separeras nationen från nationalstaten för att i stället knytas till en plats som medvetet befolkas utifrån antagen etnisk homogenitet. Denna strävan efter politisk autonomi har gett avtryck i att identitära aktörer, internationellt sett, betecknat sig själva som fria, oberoende eller autonoma nationalister (Mareš 20I4, s. 75 ff.). I Sverige har emellertid dessa benämningar, enligt AFA Dokumentations kapitel i antologin Brunt! (2007, s. 239 ff.), fått negativa laddningar hos aktörerna eftersom de associeras med 2000-talets misslyckade ambitioner att anamma den autonoma vänsterns kampstrategier och subkulturella uttryck. Ett undantag är dock nätverket Fria nationalister, med rötterna i kretsen kring Info-I4. Nätverket är aktivt från år 2005 och uppgår under $2010 \mathrm{i}$ Svenskarnas parti (Wåg 20IO, s. II7; Wåg 20I4, s. II2). Dock betecknar vanligen Sverige-baserade förmedlare av denna idéströmning, i huvudsak marknadsförd via bloggportalen Motpol, sig själva som identitärer (Motpol 20I5a; 2015b; Nydahl 20I4, s. 37 f., 47 f.).

Trots att dessa identitärer är numerärt fåtaliga tycks idéströmningen ha stor betydelse för sammanflätningen av den svenska radikalnationalismen. Idén om att frikoppla nationen från nationalstaten har exempelvis fått fäste hos Svenska motståndsrörelsen, vars "lojalitet i nuläget inte är bunden till någon specifik stat" (Lund 20I4), och hos Sverigedemokraterna som i sitt principprogram skiljer på "medborgarskap i den svenska staten och tillhörighet till den svenska nationen" (Sverigedemokraterna 2014, s. 16).

När territoriella gränsdragningar anses föränderliga stabiliseras nationalismen alltså med hjälp av dess andra grundpelare: den etniskt homogena folkgemenskapen. Förespråkandet av etnisk homogenitet har genom den identitära idéströmningen artikulerats utifrån idén om etnopluralism: etnisk särskiljning utan rangordning (Deland m.fl. 20IO, s. 9, II; Rydgren 20IO, s. I9 ff.). Även här tycks det finnas kontaktytor mellan socialkonservativ och rasorienterad nationalism. Nedanstående citat 
illustrerar hur tydliga etniska gränsdragningar kombineras med rättighetsaspekter, en direkt tillämpning av etnopluralismens grundtanke. I sitt principprogram från 20II fastslår Sverigedemokraterna:

De unika och olikartade identiteter som mänsklighetens olika folk och folkgrupper uppvisar är betingade av deras respektive kulturer. De skilda kulturerna är mänsklighetens gemensamma arv och bör erkännas och skyddas till allas gagn (Sverigedemokraterna 20I4, s. 19).

Idén att olika folkgrupper bör erkännas och respekteras, men att dessa samtidigt bör hållas separerade för att kunna bevaras, återfinns även hos Svenska motståndsrörelsen. I en intern intervju, från maj 20I5, talar rörelsens ledare om folkgemenskap i termer av solidaritet och samförstånd:

Man kan jämföra [folkgemenskap] med att man ser rasen som en större familj. Att i första hand vara solidarisk med sin familj innebär ju inte att man hatar alla andra familjer, bara att man naturligt ser till sin egen familjs intressen först. [...] Nationalsocialister strävar efter folkgemenskap, minskade klassklyftor och mer samförstånd och samarbete. Vi strävar inte efter att skapa ett segmenterat klasssamhälle, utan ser folkgemenskapstanken som något som naturligt kan minska klyftorna inom en stat (Lund 20I5).

Citaten från Sverigedemokraterna och Svenska motståndsrörelsen illustrerar hur kategoriska avgränsningar utifrån ras och kultur - "vithet" och "svenskhet" - artikuleras med hjälp av kategorin "folk". Aktörerna tycks dela uppfattningen att olika folkgrupper kan samexistera, att bevarandet av den egna nationella identiteten kan kombineras med erkännande av andra folkgrupper. Den identitära idéströmningen skapar på så sätt genom etnopluralismens transnationella anslag - ideologiska kontaktytor som överskrider den radikala nationalismens historiska splittringar. Efter sekelskiftet konkretiseras denna hopfogning, när kopplingarna mellan det radikalnationalistiska flätverkets aktörer blir allt tätare.

Under år 1999 stigmatiseras den svenska radikalnationalismen, till följd av en rad mord och attentat utförda av individer med direkt anknytning till flätverkets olika aktörer. Men när ett ungdomsbråk med dödlig utgång inträffar år 2000 i Stockholmsförorten Salem, ser personerna bakom Info-I4 nya möjligheter att återigen artikulera den radikala nationalismen. De så kallade Salemmarscherna samlar, under det tidiga 
oo-talet, tusentals personer till årliga politiska manifestationer som sammanför en rad olika aktörer (Lööw 20I5, s. 80 ff.; AFA Dokumentation 2007, s. 223). Särskilt betydelsefullt i detta enande är den begreppsmässiga nyorienteringen, där etnopluralistiska uttryck som "svenskfientlighet" och "omvänd rasism" nu blir alltmer förekommande. Den drivande aktören bakom Salemmarschen, Info-I4, hämtar på detta sätt sin artikulationskraft från den identitära idéströmningens begreppsvärld.

En grupp som särskilt betonar potentialen i en begreppsmässig nyorientering är Nordiska förbundet, en tankesmedja som grundas år 2004 efter en kris inom Nationaldemokraterna. En före detta VAM-aktivist och utgivare av tidningarna Storm och Nordland blir tongivande i den nya organisationen (Wåg 20IO, s. I07). Nordiska förbundet organiserar ett flertal projekt i syfte att bedriva en "kulturkamp" för främjande av nationalistisk politik i linje med identitära tankar (Wåg 20I0, s. Io8). Tre av Nordiska förbundets mer framgångsrika projekt blir bloggen Motpol, internetuppslagsverket Metapedia och nätforumet Nordisk.nu (Wåg 20Io, s. IIo ff., II3 f.; Nydahl 20I4, s. 47, 77 f.).

Personer från Nordiska förbundet har under 20I0-talet skapat allt större kontaktytor utanför den egna projektkretsen, bland annat genom kopplingar mellan förlagets författare, Svenskarnas parti och mediaprojektet Motgift (Svenskarnas parti 20II; Jakobsson 20I2; Nydahl 20I4, s. 74 ff.). När Nordiska förbundet läggs ner år 20Io startas i dess ställe förlaget Arktos för att fortsätta sprida identitära idéer (Expo 2015a). Arktos vd är också initiativtagare till Identitär Idé, en Stockholmsbaserad årlig konferens centrerad kring den identitära idéströmningen. Därtill är han vd för ett gruvbolag där Sverigedemokraternas tidigare partisekreterare är styrelseledamot (Finnsiö 20I6). Samma person har dessutom skrivit för den kontrajihadistiska tidningen Dispatch International, vars redaktör i sin tur varit gästkrönikör på bloggen Motpol (Carlqvist 20I4; Friberg 2013; Identitär Idé 2015). Länken mellan Arktos och Sverigedemokraterna samt mellan Motpol och Dispatch International skapar på detta sätt direkta kontaktytor med den socialkonservativa nationalismen.

Också sprungen ur Nationaldemokraterna är organisationen Nordisk ungdom, som enligt Expo (2015b) bildas av personer som varit ledande inom Nationaldemokraternas ungdomsförbund. Nordisk ungdom ger 
ut identitär litteratur och har vid upprepade tillfällen uttryckt stöd för Sverigedemokraternas ungdomsförbund, som återuppstått 1998. SDU producerar år 20I4 i sin tur en reklamfilm med budskapet "Europe belongs to us" med tydlig inspiration hämtad från de franska identitärerna i organisationen Génération identitaire (Leman 20I4; Sverigedemokratisk ungdom 20I4). Sverigedemokraternas partiledning markerar vid upprepade tillfällen mot ungdomsförbundet och anklagar dess ledning för kopplingar till "identitärer" och "neofascister", samt för att sanktionera dubbelanslutning i SDU och Nordisk ungdom (se exempelvis SD-kuriren 2015). Under våren 2015 utesluts ett antal ledande personer från SDU ur Sverigedemokraterna, och i september samma år meddelar partistyrelsen att partiet formellt bryter med ungdomsförbundet (Sverigedemokraterna 20I5). I dess ställe startas ett nytt ungdomsförbund som får namnet Ungsvenskarna Sverigedemokratisk ungdom.

Vidare har Nordisk ungdom också deltagit i politiska manifestationer tillsammans med Svenskarnas parti och organiserat medborgargarden under upploppsvågen i Stockholms förorter våren 2013 (Svenskarnas parti 20IO; Nydahl 20I4, s. 66 ff.; Expo 20I5b). Nordisk ungdom och kretsen kring Arktos förlag gestaltar på detta sätt hur den identitära idéströmningen lyckas fläta samman rasorienterade och socialkonservativa aktörer. I flödesschemat på sidorna 58-59 nedan illustreras vår sammansättning av detta historiska flätverk - kopplingarna mellan politiska partier, utomparlamentariska grupper och tankesmedjor - som bildats under hundra år av radikal nationalism.

\section{Nationalism som meningsskapare}

Ett genomgående tema för de ovan kartlagda aktörerna är ambitionen att söka sig till nationalismens ideologiska rot (radix) - idén om folkets anknytning till platsen (natio). I den historiska nationalsocialismen betonas det genetiska arvet som grundförutsättning för populationens avgränsning (och särställning). Mot slutet av 1900-talet passerar rasideologin genom den identitära idéströmningen. Den modifieras till en förståelse av etnicitet som trögföränderlig och kulturellt betingad, och på detta sätt nedärvd. Samtidigt som identitära idéer influerar den rasorien- 
terade nationalismen ger idéströmningen också bränsle åt den socialkonservativa föreställningen om nationens begränsade toleransnivå för kulturellt främmande element. Det territoriella anspråket är ett lika starkt sammanlänkande tema. Inom den socialkonservativa nationalismen utgör nationalstaten den huvudsakliga gränsdragningen för etnisk sammanhållning, en föreställning som förstärks av de rasorienterade nationalister som förordar ett militariserat, om nödvändigt utomparlamentariskt, försvar gentemot "rasfientliga" element.

Sammanflätningen av den rasorienterade och socialkonservativa nationalismen har med andra ord underlättats med hjälp av den identitära idéströmningen. Medan Salemmarschen fogade samman stora delar av det radikalnationalistiska flätverket under det tidiga 2000-talet har det identitära idékomplexet i dag skapat nya beröringsytor mellan den radikala nationalismens polariserade aktörer. Genom att betona nationell identitet i egalitära termer - den etnopluralistiska idén om att etniskt homogena folkgrupper bör leva åtskilda, om än potentiellt likställda har den identitära nationalismen gjort diskussionen om ras kontra kultur närmast överflödig, vilket förstärkt sammanfogningen av flätverket.

Etnopluralismens breda tolkningsram öppnar dessutom upp för nya tankar kring nationens territoriella omfattning. Territoriet kan motsvara gränserna för en nuvarande nationalstat som Sverige, men även andra avgränsade platser - Europa, västvärlden eller bygemenskaper - så länge detta rum befolkas av en folkgrupp som antas vara etniskt homogen. Genom att återigen betona nödvändigheten av att knyta ett specifikt folk till en specifik plats, artikulerar etnopluralismen de radikala aktörernas gemensamma ambition av att ta nationalismens idé - ett folk, ett land på fullaste allvar.

Begreppet "radikal nationalism" ökar på detta sätt precisionen med vilken vi kan förstå de studerade aktörerna. Även om sociala särskiljningsmekanismer är helt centrala för flera av de studerade aktörerna anger etnisk homogenitet endast den ena av nationalismens två grundpelare. Folkgemenskapens koppling till ett specifikt territorium löper parallellt med de radikalnationalistiska aktörernas kulturella och rasmässiga distinktioner. I analytiska termer brukar sociala indelningar utifrån kultur eller ras, kopplade till territoriella anspråk, vanligtvis betecknas 


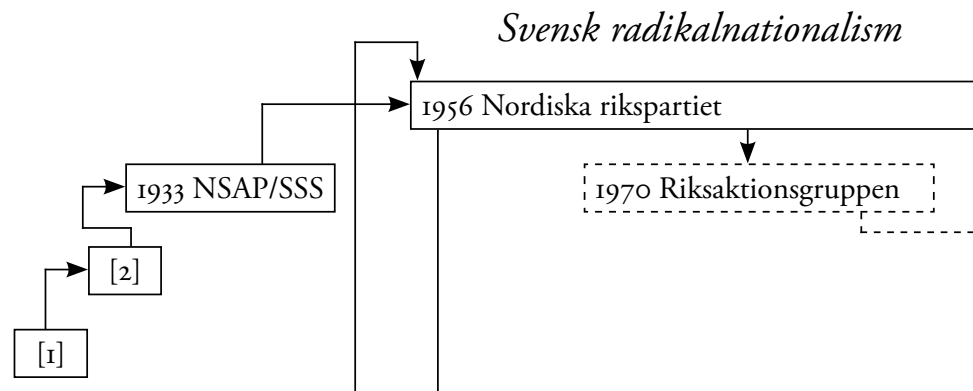

AKTÖRSFORM

Politiska partier

Utomparlamentariska grupperingar

Tankesmedjor

Figuren kan även laddas ner i en version som spänner över en hel liggande $\mathrm{A}_{4}$-sida via den beständiga länken, DOI: http://dx.doi.org/IO.I3068/2000-6217.5.2.B

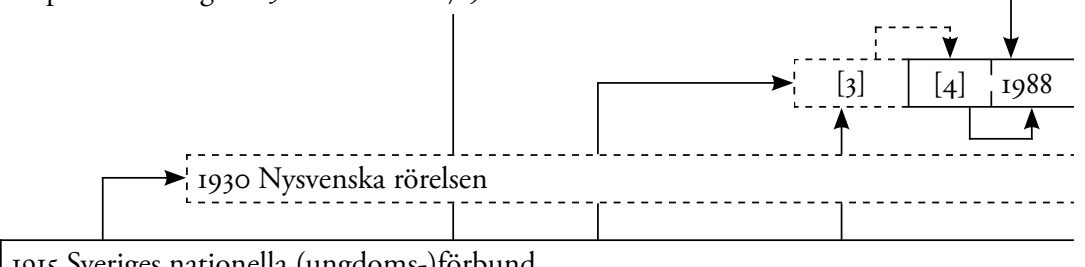

I9I5 Sveriges nationella (ungdoms-)förbund

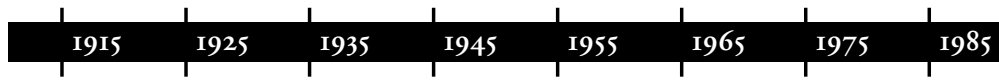

NOTER

[I] 1924 Svenska nationalsocialistiska

[6] I993 Sverigedemokratisk ungdom frihetsförbundet

[7] I995 Oberoende nationell ungdom

[2] I930 Svenska nationalsocialistiska partiet [8] 2008 Folkfronten

[3] I979 Bevara Sverige svenskt

[9] 2008 Politiskt inkorrekt

[4] I986 Sverigepartiet

[5] 1990 Storm

[1o] 20I 2 Radio framåt/Motgift

[I I] 2013 Dispatch International 
$19 I 5-20 I 5$

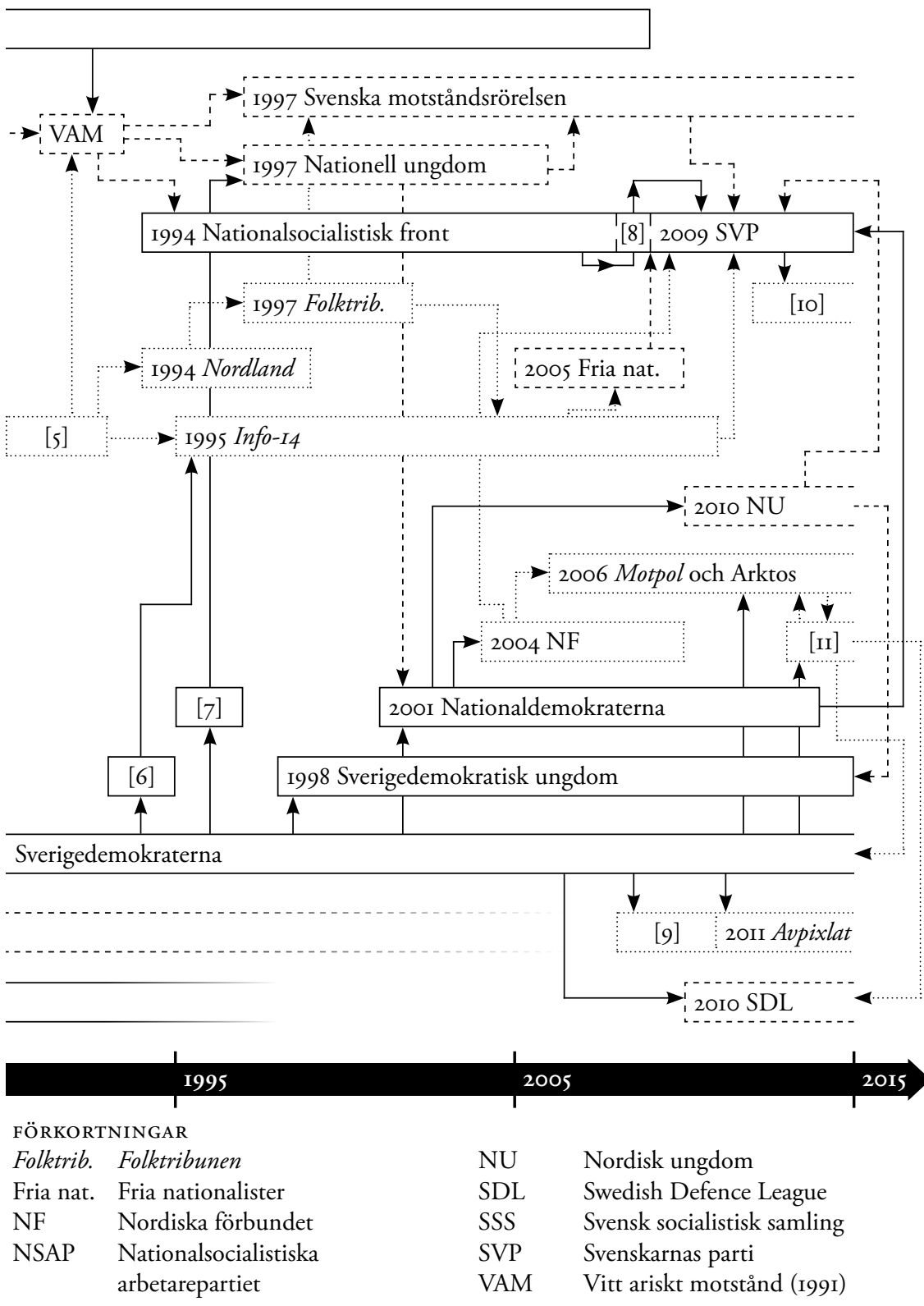


som "generisk fascism". Roger Griffins (1993, s. 44) tongivande definition betecknar fascismen som "en typ av politisk ideologi vars mytiska kärna - i sina olika gestaltningar - är en folklig ultranationalism inriktad på nationens återfödelse”.

Ett analytiskt problem med Griffins definition är att fascismen framställs som avvikande från normal nationalism. Prefixet ultra anger, precis som hos högerextremismen, att det handlar om en ideologi som förvrängts till politisk avart. Begreppets nedsättande innebörd bidrar till att osynliggöra motsvarande aktivitet i den politiska mittfåran, där det per definition inte finns någon extremism. Den ofta underförstådda betydelsen av politisk extremism - utomstatlig våldsanvändning i samhällsförändrande syften - riskerar att underskatta den taktiska innebörden i aktörernas framtoning. Problemet med att knyta extremismen till aktörer med aktiv våldsrepertoar är alltså att vissa tankesmedjor och politiska partier riskerar att bli understuderade.

Vår övergripande historisering av den svenska radikalnationalismen illustrerar på flera sätt denna problematik. Kartläggningen indikerar exempelvis att valet mellan parlamentarisk och utomparlamentarisk organisering, samt i vilken utsträckning organiserat våld gagnar det politiska ändamålet, ofta tycks bero på aktörernas strategiska bedömningar av det rådande politiska klimatet. Utomparlamentariskt våld som politisk metod grundläggs, historiskt sett, både med hjälp av rasorienterad och socialkonservativ nationalism. På samma gång tycks strategiska bedömningar om parlamentarisk eller utomparlamentarisk politik ha splittrat den radikala nationalismen i Sverige. Ett parlamentariskt parti behöver, för att nå politisk framgång, distansera sig från utomparlamentariskt våld. Då den socialkonservativa idéströmningen understryker långsam samhällsförändring framstår också den parlamentariska vägen som mer lämplig, vilket därmed förstärker avståndstagandet gentemot de revolutionära röster som oftast influeras av den rasorienterade nationalismen.

Här framträder ytterligare ett analytiskt problem, nämligen att den generiska fascismen ofta implicerar en revolutionär prägel, något som gjorts explicit i exempelvis Lena Berggrens Griffin-inspirerade konceptualisering (Berggren 20I4, s. 62). Problemet är att den socialkonservativa nationalismen per definition inte är revolutionär, utan just konservativ. 
Berggren (20I4, s. 67 ff.) försöker lösa detta problem genom att, via historikern Stanley Payne, laborera med begreppet "radikalkonservatism" som en hybrid mellan högerauktoritära och fascistiska ideologier. Trots dessa konceptuella modifikationer tycks fascismbegreppet förbli ett otillfredsställande trubbigt analysverktyg. Detta tydliggörs inte minst när en aktör som Sverigedemokraterna ska studeras. I Heléne Lööws historisering, där Sverigedemokraterna tilldelas relativt begränsat utrymme, faller aktören många gånger utanför studiens huvudfokus. Sverigedemokraterna beskrivs här som ett "extremnationalistiskt parti", och behandlas följaktligen som ett samhällsfenomen analytiskt separerat från "vit maktmiljön" (Lööw 2015, s. I82, 230).

De begrepp som står till buds tycks med andra ord sakna tillräcklig analytisk precision, i synnerhet för att placera en aktör som Sverigedemokraterna i ett bredare ideologiskt sammanhang. För att undvika analytiska inlåsningar av detta slag har vi i stället utgått från det samlande begrepp som tycks vara meningsbärande för aktörerna själva. Vår konceptualisering utgår från idén om ett specifikt folks anknytning till ett specifikt territorium - från idén om nationalismen. Aktörerna i vad vi kallar det svenska radikalnationalistiska flätverket har gemensamt att de, i varierande grad, ämnar gå till nationalismens själva rot. Detta politiska projekt kan alltså förstås som radikal nationalism.

Vi menar att det finns en analytisk potential i att tala om olika grader, i stället för former, av nationalism. Denna gradskillnad sträcker sig från det mest illojala förhållandet till nationen, till den radikala variant som fullt ut bejakar nationalismens löften. Vårt argument är att de aktörer i Sverige, som själva definierar sig som nationella, eller nationalister, är just radikala eftersom de betonar det svenska folkets exklusiva rätt till ett specifikt territorium, till den plats vi i dag kallar Sverige. Precis som andra moderna nationalstater bygger Sveriges politiska system på idén om ett specifikt territorium tillskrivet en avgränsad population. Den statliga maktens tekniker - för att tala med Foucault (2008 [1976], s. 230 ff.) inbegriper på samma gång gränssättningar gentemot andra befolkningar och ständiga kontroller av den egna befolkningens gemensamma kropp. Nationalismen behöver på detta sätt olika särskiljningsmekanismer för att motivera sina territoriella anspråk. 
Som praktik betraktad utmanas emellertid nationalismen ständigt av att befolkningar förändras och att territorier omförhandlas. Trots att varje politiskt parti per definition är nationalistiskt, i sin strävan att kontrollera den statsapparat som administrerar folkgruppens gränser, kan det ändå uppfattas som om vissa är mer villiga att kompromissa med nationalismen. Och som svar på detta svek - denna illojalitet mot nationen - strävar flätverkets aktörer efter att betona och (åter)koppla en självidentifierad folkgemenskap till ett specifikt landområde. Dessa aktörer är, med andra ord, radikala nationalister.

Idén om en nedärvd folkgemenskap, knuten till ett specifikt territorium, är på intet sätt en extrem avart till nationalismen. Tvärtom. ”Ett land, ett folk" är nationalismens själva kärna. Den radikala nationalismen är ett politiskt projekt som söker befästa och försvara nationalismens grundläggande principer. Den utvidgade analytiska räckvidd som följer på denna konceptualisering möjliggör alltså identifierbara kopplingar mellan olika grader av nationalism. Från denna horisont kan vi, förhoppningsvis, tydligare se svårigheterna med att bekämpa nationalistisk radikalisering med hjälp av det politiska system som i sig självt är avhängigt nationalismen.

\section{Referenser}

\section{Primärkällor}

Carlqvist, Ingrid 20I4. ”Nu är det ledarskribenternas tid”, från bloggen Motpol, I7 juni 2014.

URL: http://www.motpol.nu/gastkronikor/20I4/o6/I7/infor-identitar-ide-ingridcarlquist/ (9 november 2015)

Eriksson, Dan 20I4. "Den svenska nationalstaten är död”, från bloggen Motgift, I9 juni 2014 .

URL: https://www.motgift.nu/20I4/o6/den-svenska-nationalstaten-ar-dod/ (9 november 2015)

Friberg, Daniel 2013. "Tio tips till politiskt trakasserade", Dispatch International, I2 december 2013 .

URL: http://www.d-intl.com/2013/I2/ı2/tio-tips-till-politiskt-trakasserade/ (9 november 2015)

Identitär Idé 20I5. Tidigare konferenser, sida på Identitär Idés webbplats, hämtat I9 februari 2015.

URL: http://www.identitet.org/tidigare-ar/ 
Lund, Klas 20I4. "Nationalsocialismen i vår tid", Nordfront, 27 maj 2014. URL: https://www.nordfront.se/nationalsocialismen-var-tid.smr (9 november 2015)

Lund, Klas 20I5. "Samtal med Klas Lund, del 3", från Radio Nordfront, 25 maj 2015. URL: https://www.nordfront.se/samtal-med-klas-lund-del-3.smr (9 november 2015)

Magnusson, Hans 20I4. "Nationalsocialismen - vår grundpelare”, Nordfront, 2I december 2014 .

URL: https://www.nordfront.se/nationalsocialismen-var-grundpelare.smr (9 november 2015)

Motpol 20I5a. "Om Motpol", hämtat Io februari 2015.

URL: http://www.motpol.nu/om-motpol/

Motpol 2orsb. "Våra medarbetare", hämtat Io februari 2015.

URL: http://www.motpol.nu/vara-medarbetare/

SD-kuriren 2015. "Kopplingen mellan identitärerna och SDU-ledningen", 26 april 2015. URL: https://sdkuriren.se/kopplingen-mellan-identitarerna-och-sdu-ledningen/ (2I januari 20I6)

Svenskarnas parti 20IO. Svenskarnas parti högtidlighöll Karl XII:s minne, notis publicerad 7 december 20 Io på Svenskarnas partis webbplats.

URL: https://www.svenskarnasparti.se/2010/ı2/o7/svenskarnas-parti-hogtidlighollkarl-xii-minne/ (inaktiv länk, hämtat I8 februari 20I5)

Svenskarnas parti 20II. Intervju med Jonas De Geer, intervju publicerad I november $201 \mathrm{I}$ på Svenskarnas partis webbplats.

URL: https://www.svenskarnasparti.se/20II/II/oI/intervju-med-jonas-de-geer/

(inaktiv länk, hämtat I8 februari 2015)

Sverigedemokraterna 20I4. Sverigedemokraternas principprogram 20II. Tryckversion 2.0, 24 februari 2014 .

URL: https://sd.se/wp-content/uploads/2013/o8/principprogrammet20I4_webb.pdf (9 november 2015)

Sverigedemokraterna 2015. Sverigedemokraterna bildar ny ungdomsverksamhet, nyhet publicerad I2 september 2015 på Sverigedemokraternas webbplats.

URL: https://sd.se/sverigedemokraterna-bildar-ny-ungdomsverksamhet/ (2I januari 20I6)

Sverigedemokratisk ungdom 20I4. Salute to the European Youth, reklamfilm publicerad på YouTube 27 maj 2014.

URL: https://www.youtube.com/watch?v=VR-1AGj_dlQ (9 november 20I5)

\section{Litteratur}

AFA Dokumentation 2007. "Oberoende nationalister. Organisationslösheten som organisationsform", i Deland, Mats \& Westin, Charles (red.) Brunt! Nationalistisk och nazistisk mobilisering $i$ vår närmaste omvärld under efterkrigstiden. Stockholm: Atlas.

Berggren, Lena 20I4. Blodets renhet. En historisk studie av svensk antisemitism. Malmö: Arx förlag.

Cento Bull, Anna 2009. "Neo-fascism", i Bosworth, Richard (red.) The Oxford Handbook of Fascism. Oxford: Oxford University Press. 
Deland, Mats, Hertzberg, Fredrik \& Hvitfeldt, Thomas 20ıо. "Förord", i Deland, Mats, Hertzberg, Fredrik \& Hvitfeldt, Thomas (red.) Det vita fältet. Samtida forskning om högerextremism. Uppsala: Opuscula historica Upsaliensis 4I. URL: http://urn.kb.se/resolve?urn=urn:nbn:se:uu:diva-I39645

Ekman, Mikael 20I3. "Ett radikalare alternativ till SD", i rapporten Intolerans I2. En airsrapport från Stiftelsen Expo från Expo Research, s. 4-5.

URL: http://expo.se/www/download/Expo_Intolerans_I2.pdf (9 november 2015)

Ekman, Mikael 20I4. "Drömmen om ett rent Sverige", i Axelsson, Madelene \& Borg, Kristian (red.) Sverigedemokraternas svarta bok. Stockholm: Verbal förlag.

Expo 2012. "Biografier", bilaga till rapporten Counterjihadrörelsen - en del av den antimuslimska miljön från Expo Research.

URL: http://expo.se/www/download/Bilaga_Biografier_counterjihadrorelsen_2OI2. pdf (9 november 20I5)

Expo 20I5a. Nordiska forbundet, sida på webbplatsen Expo Skola, hämtat I8 februari 2015. URL: http://skola.expo.se/nordiska-forbundet_I2o.html

Expo 20I5b. Nordisk ungdom, sida på webbplatsen Expo Skola, hämtat I8 februari 2015. URL: http://skola.expo.se/nordisk-ungdom_II7.html

Finnsiö, Morgan 20I6. "Erik Almqvist investerar i nyfascisters gruvbolag", Expo Idag, 20 januari 2016.

URL: http://expo.se/20I6/erik-almqvist-investerar-i-nyfascisters-gruvbolag_70IO.

html (2I januari 2016)

Fleischer, Rasmus 20I4. "Two Fascisms in Contemporary Europe? Understanding the Ideological Split of the Radical Right", i Deland, Mats, Minkenberg, Michael \& Mays, Christin (red.) In the Tracks of Breivik. Far Right Networks in Northern and Eastern Europe. Berlin: Lit Verlag.

Foucault, Michel 2008 [1976]. "Föreläsning den 17 mars 1976", i Foucault, Michel, "Samhället måste försvaras". Collège de France 1975-1976. Hägersten: Tankekraft förlag.

Gardell, Mattias 2007. "Rasstaten och dess försvarare - om vithet, nationalsocialism och vitmaktkultur i Förena Staterna", i Deland, Mats \& Westin, Charles (red.) Brunt! Nationalistisk och nazistisk mobilisering i vår närmaste omvärld under efterkrigstiden. Stockholm: Atlas.

Griffin, Roger 1993. The Nature of Fascism. London: Routledge.

Hannus, Martha 2012. Counterjihadrörelsen - en del av den antimuslimska miljön, rapport från Expo Research.

URL: http://expo.se/www/download/counterjihadrorelsen_en_del_av_den_ antimuslimska_rorelsen_20I2.pdf (9 november 20I5)

Jakobsson, Johannes 20I2. "Vit makt-veteraner samlas i Svenskarnas parti”, Expo Idag, I3 april 2012.

URL: http://expo.se/20I2/vitmakt-veteraner-samlas-i-svenskarnas-parti_4928.html

(9 november 2015)

Leman, Jonathan 20I4. "Dokument: Striden mellan SD och SDU", Expo Idag, 28 november 2014 .

URL: http://expo.se/20I4/dokument-striden-mellan-sd-och-sdu_672o.html (9 november 20I5) 
Lundberg, Victor 20I4. En idé större än döden. En fascistisk arbetarrörelse i Sverige, 19331945. Möklinta: Gidlund.

Lööw, Heléne 1990. Hakkorset och Wasakärven. En studie av nationalsocialismen i Sverige I924-I950. Göteborg: Göteborgs Universitet.

Lööw, Heléne 2000. Nazismen i Sverige 1980-1999. Den rasistiska undergroundrörelsen: musiken, myterna, riterna. Stockholm: Ordfront.

Lööw, Heléne 2004. Nazismen i Sverige 1924-1979. Pionjärerna, partierna, propagandan. Stockholm: Ordfront.

Lööw, Heléne 2007. "Det förflutnas skuggor”, i Deland, Mats \& Westin, Charles (red.) Brunt! Nationalistisk och nazistisk mobilisering i vår närmaste omvärld under efterkrigstiden. Stockholm: Atlas.

Lööw, Heléne 2015. Nazismen i Sverige 2000-2014. Stockholm: Ordfront.

Mareš, Miroslav 20I4. "Far Right Youth Transnational Cooperation in East Central Europe", i Deland, Mats, Minkenberg, Michael \& Mays, Christin (red.) In the Tracks of Breivik. Far Right Networks in Northern and Eastern Europe. Berlin: Lit Verlag.

Mosse, George 1996. The Image of Man. The Creation of Modern Masculinity. Oxford: Oxford University Press.

Norocel, Ov Cristian 20ı3a. "Antifeminism och maskulinitet - Manliga ideal inom högerradikal populism i Norden", i Hvordan motarbeide antifeminisme og høyreekstremisme? Innspill og anbefalinger fra eksperter i Norden. Rapport fra ekspertseminar i Oslo 29. og 30. november 20I2, rapport från Reform - ressurssenter for menn.

URL: http://reform.no/wp-content/uploads/20II/os/ANTIFEMINISME.pdf (9 november 2015)

Norocel, Ov Cristian 20I3b. "Konstruktionen av högerradikala populistiska maskuliniteter i Sverige. En feministisk analys", i Det vita fältet II. Samtida forskning om högerextremism, specialnummer av Arkiv. Tidskrift för sambällsanalys, nr 2, s. 45-67. DoI: http://dx.doi.org/IO.I3068/2000-6217.2.2

Nydahl, Thomas 20I4. Identitärt. Om rötter, identitet och politisk aktivism. Kristianstad: Occident.

Quensel, Anna-Sofia 20I4. "Counterjihadrörelsen - liten men högljudd", i rapporten Intolerans 13. En årsrapport från Stiftelsen Expo från Expo Research, s. 42-43.

URL: http://expo.se/www/download/Intoleransi3_inlaga_EXPO-I-20I4.pdf (9 november 20I5)

Rydgren, Jens 20I0. "Den radikala högerns sociologi", i Deland, Mats, Hertzberg, Fredrik \& Hvitfeldt, Thomas (red.) Det vita fältet. Samtida forskning om högerextremism. Uppsala: Opuscula historica Upsaliensis 4I.

URL: http://urn.kb.se/resolve?urn=urn:nbn:se:uu:diva-I39645

Straud, Torulf 2007. "Socialism bara för tyskar", i Deland, Mats \& Westin, Charles (red.) Brunt! Nationalistisk och nazistisk mobilisering i vår närmaste omvärld under efterkrigstiden. Stockholm: Atlas.

Wåg, Mathias 20Io. ”Nationell kulturkamp - från vit maktmusik till metapolitik", i Deland, Mats, Hertzberg, Fredrik \& Hvitfeldt, Thomas (red.) Det vita fältet. Samtida forskning om högerextremism. Uppsala: Opuscula historica Upsaliensis 4I.

URL: http://urn.kb.se/resolve?urn=urn:nbn:se:uu:diva-I39645 
ARKIV | NR S | DET VITA FÄLTET III

Wåg, Mathias 20I4. "Bruna rötter, blågul stam, bruna grenar: Sverigedemokraterna som plantskola för svensk extremhöger”, i Axelsson, Madelene \& Borg, Kristian (red.) Sverigedemokraternas svarta bok. Stockholm: Verbal förlag.

Wärenstam, Eric 1965. Sveriges nationella ungdomsförbund och högern 1928-1934. Stockholm: Svenska bokförlaget.

Wärenstam, Eric 1970. Fascismen och nazismen i Sverige 1920-1940. Studier i den svenska nationalsocialismens, fascismens och antisemitismens organisationer, ideologier och propaganda under mellankrigsairen. Stockholm: Almqvist \& Wiksell. 


\section{THOMAS MALM DEN OMÖJLIGA KEDJAN Människan och mångfaldens mönster}

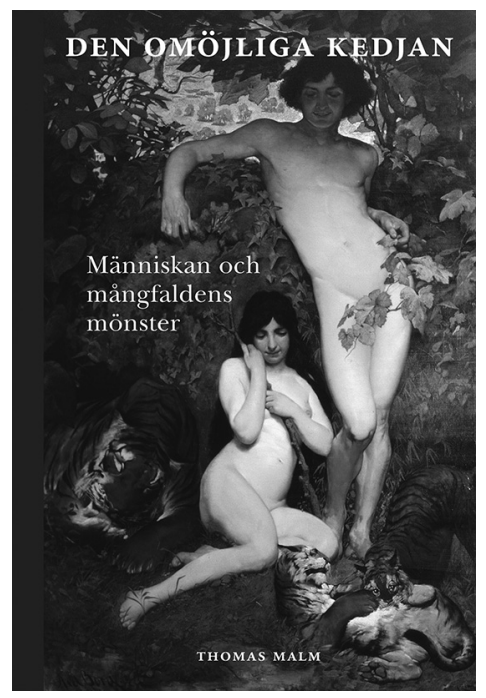

I alla tider har människor klassificerat växter, djur och varandra. Västerlänningar har sett sig själva såsom stående högt upp på en stege eller trappa, med de andra organismerna under sig, eller som en yttersta länk i "varandets stora kedja". Uttryck som "skapelsens krona", "den felande länken" och "civilisationens utkanter" blottar en världsbild som kan leda våra tankar fel och i sina värsta avarter har legitimerat rasbiologi och rasism.

Den omöjliga kedjan handlar om en av idéhistoriens mest grandiosa tanketraditioner, men till stora delar också om hopplösa idéer och mörka återvändsgränder. Med ett brett tvärvetenskapligt angreppssätt utforskar socialantropologen Thomas Malm olika aspekter av det fundamentalt mänskliga behovet av att indela, namnge och värdera omvärlden.

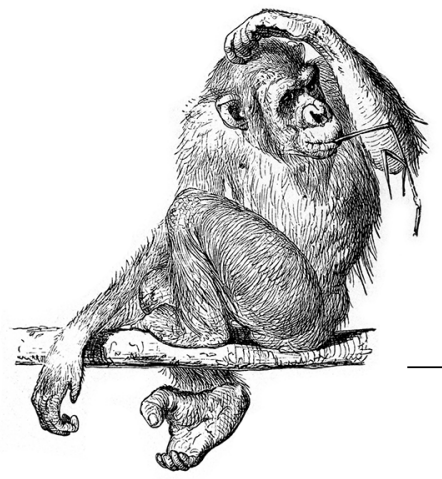

Arkiv förlag, inbunden, 424 sidor

Alla som är intresserade av hur vi - vetenskapsmän lika väl som ”vanliga människor" ... - tänker om naturen och våra medmänniskor har mycket att hämta i hans bok.

Nils Uddenberg i Dagens Nyheter

„Läs mer om boken på www.arkiv.nu« 


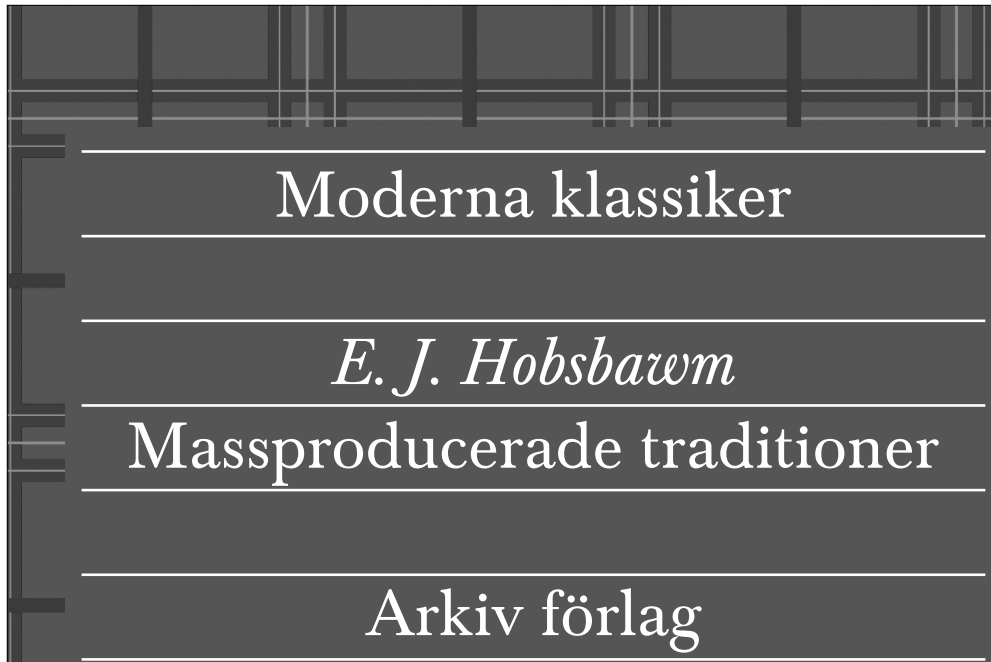

Eric J. Hobsbawm (I9I7-2OI2) var en av sin generations ledande historiker. Han har skrivit om arbetarrörelsen i England, om rebeller och banditer i Europa, om jazzen, om historieforskning med mera. Flera av hans böcker finns översatta till svenska, främst då hans historiska översikt i fyra band om tiden från den industriella revolutionen till Sovjetunionens sammanbrott. Massproducerade traditioner är den kanske mest berömda av Hobsbawms skrifter i det mindre formatet. Här visar han sin skicklighet, överblick och elegans i analysen av hur traditioner skapas och sprids.

Översättning Gunnar Sandin Arkiv förlag, 63 sidor 